\title{
Effect of high temperature and type of cooling on some mechanical properties of cement mortar
}

\author{
Faisal Abdulhussei ${ }^{1}$, Waleed Abbas $^{2}$ and Qais Frayyeh ${ }^{2, *}$ \\ ${ }^{1}$ Madenat al-Elem University College, Baghdad, Iraq \\ ${ }^{2}$ Building and Construction Engineering Department, University of Technology, Baghdad, Iraq
}

\begin{abstract}
Mortar of cement as construction materials subjected sometimes to high temperature. Some of properties of this mortar being studied after this effect. The effect of high temperature 100, 200, 400 and $700{ }^{\circ} \mathrm{C}$ (exposed for two hrs.) on some mechanical properties (compressive and flexural strength) of two groups of cement mortar samples (with and without the addition of crushed bricks and superplasticizer as modifying materials) has been studied. Two methods of cooling samples by air and by water for $1 / 2 \mathrm{hr}$. was used, then tested after 3, 7 and 28 days. The results showed that the compressive and flexural strength for reference mix exposed to $700^{\circ} \mathrm{C}$ and water cooling decreased by $65.3 \%$ and $64.7 \%$, respectively, compared with their reference mix tested at $20^{\circ} \mathrm{C}$ in 28 days. While mixes containing $100 \%$ of crushed brick as an additive and air cooling decreases by $12.3 \%$ and $9 \%$ of their compressive and flexural strength, respectively compared with the mixes tested at $20^{\circ} \mathrm{C}$ in 28 days. Also showed that the decreases in flexural strength for no sand mixes containing $100 \%$ of crushed brick and $4 \%$ of superplasticizer exposed to $700^{\circ} \mathrm{C}$ and then water cooling was $28.2 \%$ compared to those for reference mixes tested at $20^{\circ} \mathrm{C}$.
\end{abstract}

\section{Introduction}

Cement mortar as a material in service is exposed to high temperatures during fire. The main properties of cement mortar after such an exposure to fire are of great importance in terms of the serviceability of the materials.

Fire represents one of the most sever risks to buildings and structures. To find the resistance of construction materials for fire, test is performed torch for each country according to fire-fighting systems in place there. It has been found through experiments that cement mortar had bad properties in fire resistance; so many researches had been done to limit and improve the ability to withstand high temperatures.

Aydin [1] studied the effect of high temperature up to $900^{\circ} \mathrm{C}$ on the compressive strength of cement pumice mortars containing different amounts of ground granulated blast furnace slag (GGBFS). Aydin concluded that at $900^{\circ} \mathrm{C}$, the mortar containing $80 \%$ GGBFS exhibited only $23 \% \quad 23 \%$ and $28 \%$ compressive strength loss when cooled in air and water, respectively, whereas mortars without GGBFS lost almost $70 \%$ of their strength.

Aydin and Baradan [2] investigated the effects of different high temperatures on the mechanical

*Corresponding author: jwd ks@yahoo.com properties of cement pumice mortars containing fly ash. They concluded that the cement pumice mortar containing $60 \%$ of fly ash revealed the best performance particularly at $900^{\circ} \mathrm{C}$. This mixture did not show any loss in compressive strength at all test temperatures when cooled in air.

Hossain, Islam and Karim [3] studied the effect of high temperature during fire on the bond and compressive strength of cement mortar containing high volume fly ash without using any water reducing admixtures. They indicated that the mortar containing $50 \%$ fly ash as a replacement of cement exhibits greater resistance to high temperature. Also, compressive and bond strengths of mortar containing different percentages of fly ash initially increase with the increase in temperature but after $200^{\circ} \mathrm{C}$ they decrease with the further increase in temperature.

\section{The objective}

Studying the effect of high temperature on compressive and flexural strength of cement mortar, and how to decrease these effects by replacing with crushed bricks as waste materials. 


\section{Experimental works}

\subsection{Materials}

\subsubsection{Cement}

Ordinary Portland cement type (I) manufactured in Iraq with trade mark of (AL. MASS) has been used. The test results show that the cement conforms to provisions of (I.Q.S. No. 5 / 1984) [4]. Tables 1 and 2 show the chemical analysis and physical properties of cement.

\subsubsection{Crushed bricks}

The bricks that have been used in this research were waste material from Iraqi factory in Al-Nahrwan. The waste bricks were crushed to get same grading as fine aggregate used as partial or complete replacement of sand. The grading of crushed brick was shown in Table 4. It was shown that the grading of crushed brick within the same zone of sand. Also, the chemical test results indicated that specific gravity was 1.84 , sulfate content in crushed bricks was $0.34 \%$ and fine materials less than 0.075 was $3.8 \%$.

\subsubsection{Fine Aggregate (sand)}

Sand used after it has been sieved by sieve size $(4.75 \mathrm{~mm})$ with specific gravity of 2.64 , sulfate content is $0.35 \%$, and percentage of fine materials less than $0.075 \mathrm{~mm}$ was $3.4 \%$. The grading of fine aggregate was shown in Table 3. It conformed to (I.Q.S.NO. 45 1984) [5].

\subsubsection{Superplasticizer}

Superplasticizer SP 703S type A according to (ASTM C494 - 2004) [6] was used as a high range water reducing admixture by weight of cement of $(1 \%$, $2 \%$, and $4 \%$ ). Table 5 shows the chemical properties of the super plasticizer used according to manufacturer.

\subsubsection{Water}

Drinking water was used for all the mixes and for the curing process of samples.

Table 1. Chemical analysis of cement*.

\begin{tabular}{|c|c|c|c|}
\hline \multicolumn{2}{|c|}{ Components } & Test Result & Limits of I.Q.S. No. 5 / 1984 \\
\hline Lime $(\%)$ & $\mathrm{CaO}$ & 61.89 & - \\
\hline Silica (\%) & $\mathrm{SiO}_{2}$ & 21.37 & - \\
\hline Alumina $(\%)$ & $\mathrm{Al}_{2} \mathrm{O}_{3}$ & 4.6 & - \\
\hline Iron Oxide $(\%)$ & $\mathrm{Fe}_{2} \mathrm{O}_{3}$ & 3.35 & - \\
\hline Sulfate $(\%)$ & $\mathrm{SO}_{3}$ & 2.42 & $\leq 2.8 \%$ \\
\hline Magnesia (\%) & $\mathrm{MgO}$ & 3.05 & $\leq 5 \%$ \\
\hline Potash (\%) & $\mathrm{K}_{2} \mathrm{O}$ & 0.36 & \\
\hline Soda $(\%)$ & $\mathrm{Na}_{2} \mathrm{O}$ & 0.27 & \\
\hline Loss on Ignition $(\%)$ & L.O.I & 2.16 & $\leq 4 \%$ \\
\hline Lime Saturation Factor & L.S.F & 0.91 & $0.66-1.02$ \\
\hline Insoluble Residue (\%) & I.R & 0.6 & $\leq 1.5$ \\
\hline \multicolumn{4}{|c|}{ Main compound (Bogue's equation) } \\
\hline Tricalcium Silicate & $\mathrm{C}_{3} \mathrm{~S}$ & 46.95 & - \\
\hline Dicalcium Silicate & $\mathrm{C}_{2} \mathrm{~S}$ & 25.85 & - \\
\hline Tricalcium Aluminate & $\mathrm{C}_{3} \mathrm{~A}$ & 6.52 & - \\
\hline Tetracalcium Aluminoferrite & $\mathrm{C}_{4} \mathrm{AF}$ & 10.19 & - \\
\hline
\end{tabular}

Table 2. Physical properties of cement*.

\begin{tabular}{|l|c|c|}
\hline Physical Property & Test Result & $\begin{array}{c}\text { Limits of I.Q.S. No. 5/ } \\
1984\end{array}$ \\
\hline Specific Surface Area $\left(\mathrm{m}^{2} / \mathrm{kg}\right)$ & 369 & $230(\mathrm{~min})$ \\
\hline Setting time & & \\
Initial ( hrs. : min.) & $2: 00$ & $0: 45$ (min.) \\
Final ( hrs. : min ) & $3: 35$ & $10: 0$ (max.) \\
\hline Compressive strength $\left(\mathrm{N} / \mathrm{mm}^{2}\right)$ & 24.9 & \\
3 days & 29.7 & 15 (min.) \\
7 days & & 23 (min.) \\
\hline
\end{tabular}

*Test done at NCCL. 
Table 3. Grading of fine aggregate (sand).

\begin{tabular}{|c|c|c|}
\hline Sieve Size $(\mathrm{mm})$ & \% passing & Limit of I.Q.S. No. 45 - 1984 - Zone 2 \\
\hline 4.75 & 98 & $90-100$ \\
\hline 2.36 & 83 & $75-100$ \\
\hline 1.18 & 65 & $55-90$ \\
\hline 0.6 & 47 & $35-59$ \\
\hline 0.3 & 18 & $8-30$ \\
\hline 0.15 & 6.0 & $0-10$ \\
\hline
\end{tabular}

Table 4. Grading of crushed bricks

\begin{tabular}{|c|c|c|}
\hline Sieve Size $(\mathrm{mm})$ & \% passing & Limit of I.Q.S. No. $45-1984$ \\
\hline 4.75 & 100 & $90-100$ \\
\hline 2.36 & 88 & $75-100$ \\
\hline 1.18 & 70 & $55-90$ \\
\hline 0.6 & 61 & $35-59$ \\
\hline 0.3 & 19 & $8-30$ \\
\hline 0.15 & 7 & $0-10$ \\
\hline
\end{tabular}

Table 5. Properties of superplasticizer SP 703S

\begin{tabular}{|l|l|}
\hline Appearance & Dark brown / black liquid \\
\hline Specific gravity & $1.235 @ 25 \pm 2^{\circ} \mathrm{C}$ \\
\hline Chloride content & Nil \\
\hline Flash point & N / A \\
\hline
\end{tabular}

\subsection{Mix Proportioning}

The flow of the mortar was considered to mix design so that the $\mathrm{w} / \mathrm{c}$ ratio was determined according to ASTM C1437-04 [7]. The reference mortar mix was designed to have flow $80 \pm 5 \mathrm{~mm}$, the cement: sand ratio was $1: 3$ by weight and $w / c$ ratio was 0.6 . Seven mortar mixes were prepared. Its details are shown in Table 6.

\subsection{Preparation, Casting and Curing of Specimens}

The mix of the raw materials was done according to ASTM C $305-99[8]$. After conducting flow test, the specimens were prepared by casting in different standard molds. The standard molds were cleaned and oiled before casting to avoid the adhesion to sides of the molds. The mortar was placed in the molds with layers according to the standard specifications for each test and compaction by means of vibration table. The top layers of mortar specimens had been smoothed by steel trowel, and then the specimens were covered with nylon sheets for 24 hours to prevent the evaporation of water. After that the specimens were demolded and fully immersed in tap water for 28 days. At age 28 days the specimens subjected to different constant temperatures $\left(100,200,400\right.$ and $700{ }^{\circ} \mathrm{C}$ (exposed for two hrs.) in two ways. First one when the samples were oven dry and second one where the samples were fully saturated.

Table 6. Mixes proportion details (by weight)

\begin{tabular}{|c|c|c|c|c|c|c|}
\hline $\begin{array}{c}\text { Mix } \\
\text { Symbol }\end{array}$ & Cement & Sand & $\begin{array}{c}\text { Crushed } \\
\text { bricks }\end{array}$ & $\begin{array}{c}\text { SP } \\
\% \text { from } \\
\text { cement }\end{array}$ & $\begin{array}{c}\text { w/c to give flow of } \\
80 \pm 5 \mathrm{~mm}\end{array}$ & $\begin{array}{c}\text { Oven Dry density } \\
\mathrm{kg} / \mathrm{cm}^{3} \\
\text { at } 28 \text { days age }\end{array}$ \\
\hline $\mathrm{B}_{0}$ & 1 & 3 & - & - & 0.6 & 1980 \\
\hline $\mathrm{B}_{1}$ & 1 & 2.25 & 0.75 & - & 0.62 & 1840 \\
\hline $\mathrm{B}_{2}$ & 1 & 1.5 & 1.5 & - & 0.66 & 1760 \\
\hline $\mathrm{B}_{3}$ & 1 & - & 3 & - & 0.72 & 1680 \\
\hline $\mathrm{B}_{4}$ & 1 & 2.25 & 0.75 & 1 & 0.58 & 2080 \\
\hline $\mathrm{B}_{5}$ & 1 & 1.5 & 1.5 & 2 & 0.55 & 2120 \\
\hline $\mathrm{B}_{6}$ & 1 & - & 3 & 4 & 0.52 & 2180 \\
\hline
\end{tabular}




\section{Results and Discussion}

\subsection{Oven dry density}

This test was done according to ASTM C 567-05a [9] using $50 \times 100 \mathrm{~mm}$ cylindrical specimens. The results of dry density for different mortars demonstrated in Table 6 and Fig. 1. From the results, it is clear that the replacement of sand by crushed brick with $(0.25 \%, 50 \%$ and $100 \%)$ reduce the dry density of mortars with $(7.07 \%, 11.11 \%$ and 15.15$)$, respectively. The reasons of these reductions may be due to the use of supplementary material (crushed brick) which has a specific gravity much lesser than that of sand and its coarse grains. Also, the results indicated that the use of superplasticizer increase the dry density. These may be due to reduction in the w/c which needs to give flow of $80 \pm 5 \mathrm{~mm}$.

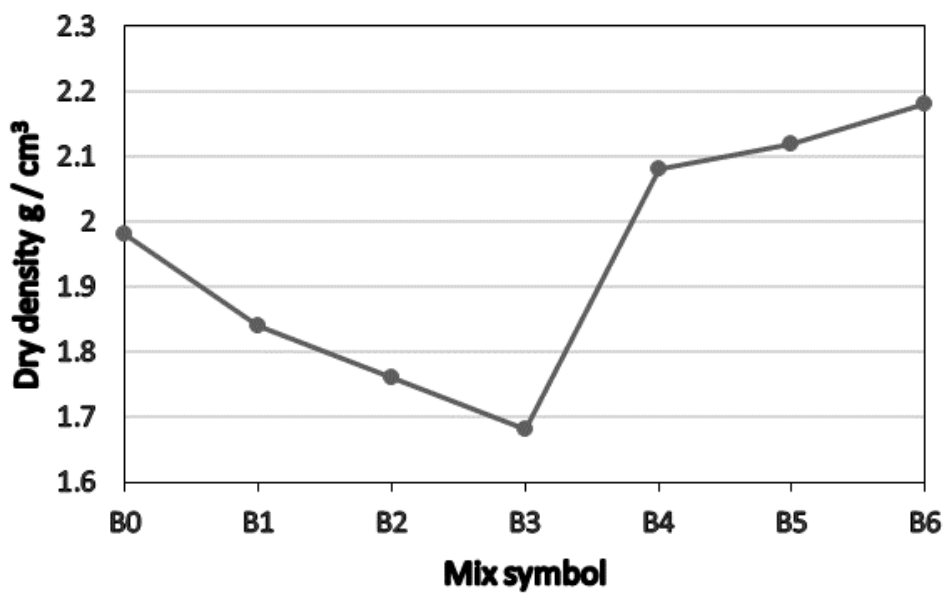

Fig. 1. Oven dry Density for different mixes tested at (28) day and curing in water at $20{ }^{\circ} \mathrm{C}$

\subsection{Compressive Strength}

This test was done according to ASTM C 109-02 [10] using $50 \mathrm{~mm}$ cube specimens. From the results, it's clear that the use of water curing is better than air curing methods and this is in conformity with the findings of the earlier researchers. The use of super plasticizer for specimens $\left(\mathrm{B}_{4}, \mathrm{~B}_{5}\right.$ and $\left.\mathrm{B}_{6}\right)$ with percent of $(1 \%, 2 \%$ and $4 \%)$, respectively reduces the ratio of (w/c) which increases the compressive strength to ensure good workability (Shirkavand and Baggott, R,1995[11]) (Fig. 2. \& 3.). Also, the results indicated that the compressive strength of specimens without replacement of sand by crushed bricks when exposed to $700^{\circ} \mathrm{C}$ dropped by $(37.1 \%)\left(\mathrm{Mix}_{0}\right)$, while this drop reduced to $(19.5 \%)$ when the total sand was replaced by crushed bricks (Mix $\mathrm{B}_{6}$ ). This reduction of drops referred may be related to the use of refractory materials (crushed bricks) which had stability when exposed to high temperatures compared with sand.

From Fig. 3, the values of compressive strength were achieved when tested at age of (28) days for specimens $\left(\mathrm{B}_{6}\right)$ and exposed to heating of $(700){ }^{\circ} \mathrm{C}$ which represents an increase of $(163.15 \%)$ compared to reference mortar specimens $\left(\mathrm{B}_{0}\right)$ when exposed to heating of (700) ${ }^{\circ} \mathrm{C}$ and tested at age (28) days. These results are the same researchers results of (Ahmed, A. $\mathrm{H}$ and Abdul Kaream, O.M,2010[12]) and these may be due to reduction of required water which increases strength and reduces voids.

The results showed there is a big loss in compressive strength for the reference mortar specimen $\left(\mathrm{B}_{0}\right)$ when exposed to high temperature tested at (28) days as shown in Fig. $2 \& 3$ and this suits the result archived by the researcher (Aydin \& Baradan , 2007[2]) which included "The loss of the mortar exposed to high heating temperature treated with water is greater than the loss in compressive strength for the mortar at the same condition treated with air".

Fig. 4 represents the relationship between compressive strength with dry density for cement mortar for different mixes tested at (28) days and cured in water at $20^{\circ} \mathrm{C}$. It's clear to observe that the relations between compressive strength and dry density are positive. 


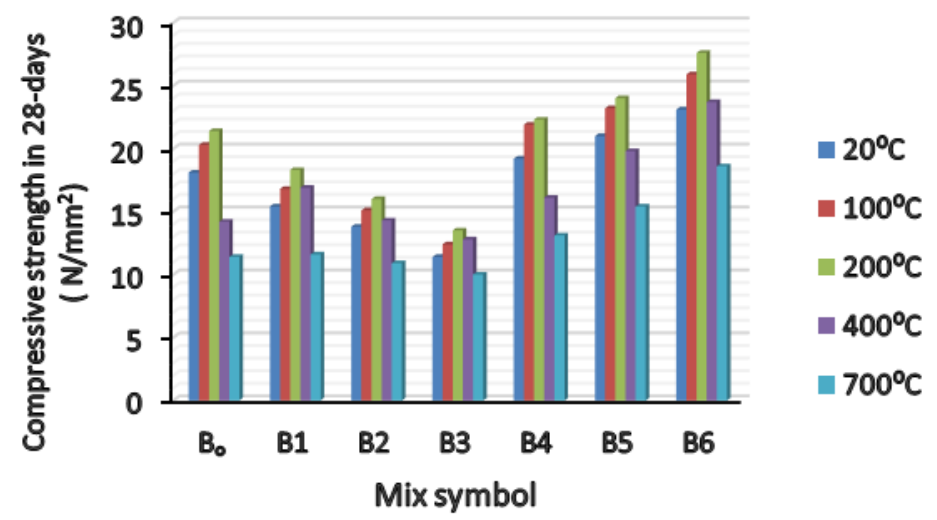

Fig. 2. Compressive strength in 28-days for different mixes of mortars cooled with air and exposed to different temperature

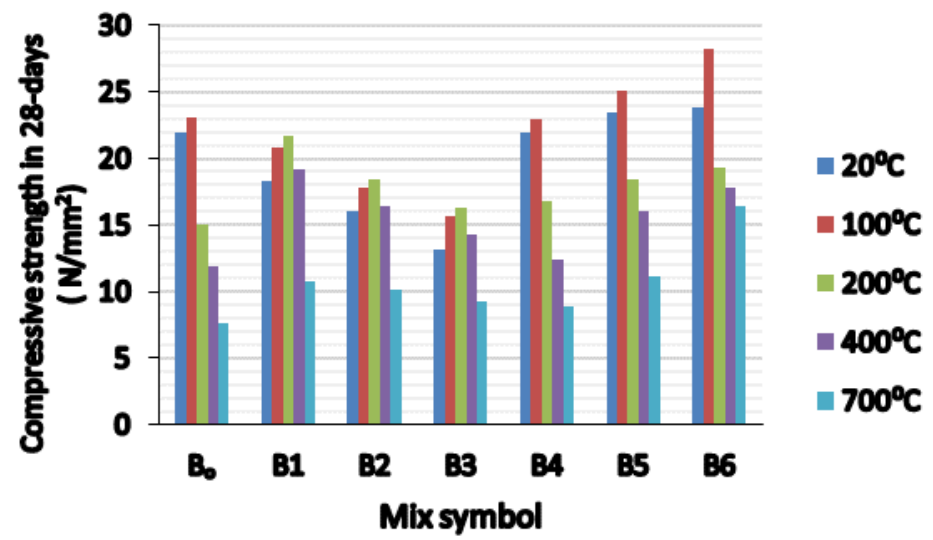

Fig. 3. Compressive strength in 28-days for different mixes of mortars cooled with water and exposed to different temperature

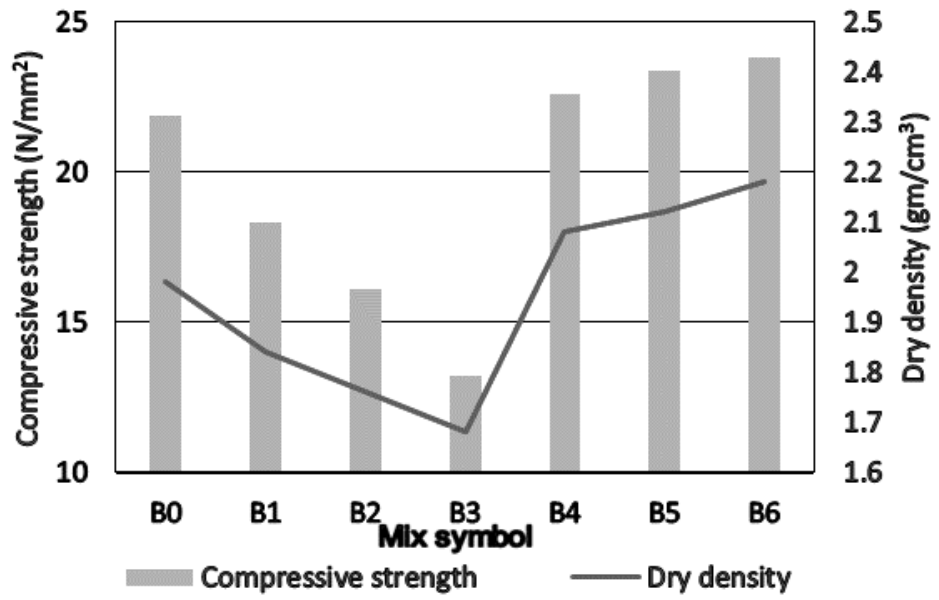

Fig. 4. The relationship between compressive strength and the dry density for different mixes tested at (28) day and cured in water at $20^{\circ} \mathrm{C}$

\subsection{Flexural Strength}

This test was done according to ASTM C348-02 [13] using $40 \times 40 \times 160 \mathrm{~mm}$ prism specimens. The result values for flexural strength for all mixes exposed to different heating temperatures for half hour after treatment with air or water and then tested are shown in Fig. 5. \& 6. 


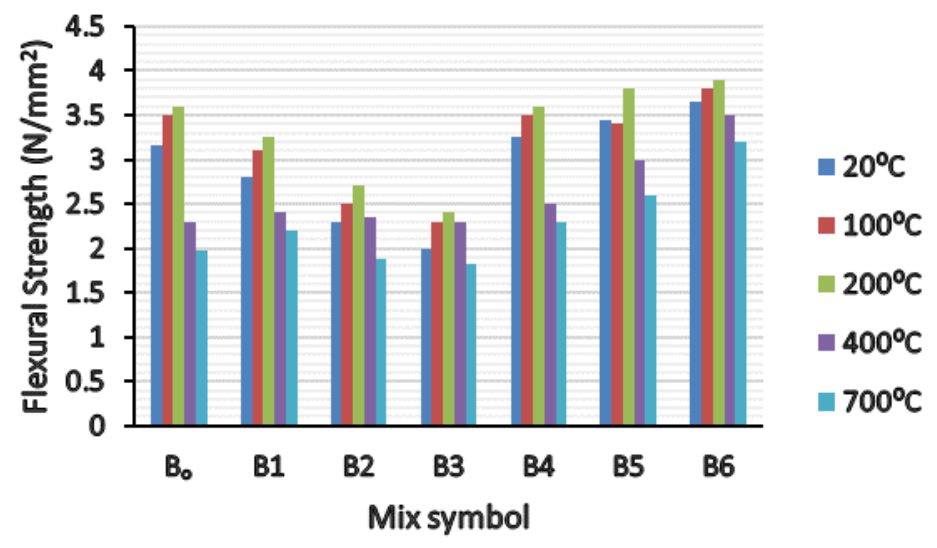

Fig. 5. Flexural Strength in 28-days for different mixes cooled by air and exposed to different temperature

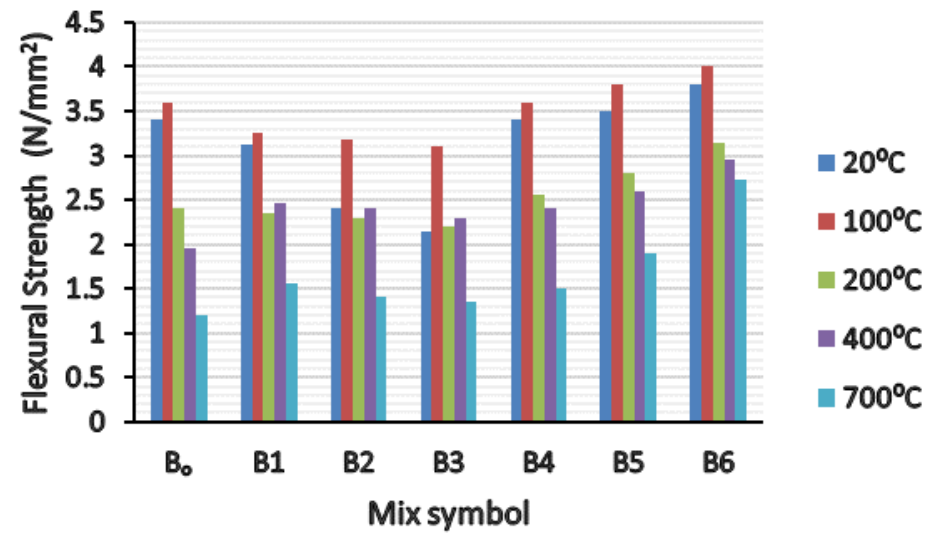

Fig. 6. Flexural Strength in 28-days for different mixes cooled by water and exposed to different temperature

From the results, it's clear that the use of water curing gives good results compared with air curing methods and this is also in conformity with the findings of the earlier researchers as for compressive strength.

For the specimens exposed to different heating temperatures for half hour after being treated with water and tested, the results showed the loss in flexural strength was huge (between $28.2 \%$ - 64.7\%), especially for those specimens exposed to $(700)^{\circ} \mathrm{C}$ and tested at (28) days for specimens $B_{0}$ to $B_{6}$ respectively, which was about double the loss for the same specimens treated with air after being exposed to heating degree as shown in Fig. $5 \& 6$ this result doesn't counter the research (Aydin, 2007[2]) .Many authors (Georgali B. , and Taskiridis P. E,2005[14], Fu Y.F. ,et all ,2004[15], Serdar A. ,et all ,2008 [16] and Fares , Noumoure ,and Remond,2004[17]) agree on the fact that strength decreases with increasing temperature of exposure.

From Fig. 6, the values of compressive strength were achieved when tested at age of (28) days for specimens $\left(\mathrm{B}_{6}\right)$ and exposed to heating of $(700){ }^{\circ} \mathrm{C}$ which represents increase by percent of (127. 5\%) compared to reference mortar specimens $\left(\mathrm{B}_{0}\right)$ when exposed to heating of (700) ${ }^{\circ} \mathrm{C}$ and tested at age (28) days. These may be due to reduction of required water which increases strength and reduces voids.
Fig. 5 shows the loss of strength at highest heating degree of temperature (700) ${ }^{\circ} \mathrm{C}$ tested at age (28) days with percent of $(37.3 \%, 9 \%$ and $12.3 \%)$ for specimens $\left(\mathrm{B}_{0}, \mathrm{~B}_{3}\right.$ and $\left.\mathrm{B}_{6}\right)$, respectively compared to the same specimens when tested at the same age with heating degree of $(20)^{\circ} \mathrm{C}$, while Fig. 8 showed the relation of the percentage of loss of strength at highest temperature $(700)^{\circ} \mathrm{C}$ between the specimens treated with air and others treated with water.

\section{Conclusions}

From the experimental results presented in this research, the following conclusions can be drawn:

1- All specimens exposed to a temperature of $700^{\circ} \mathrm{C}$ showed a decrease in their compressive and flexural strengths. The difference in the strength decrease was relatively different between specimens treated with water and those left in air to dry compared to the reference specimens tested at $20^{\circ} \mathrm{C}$ after $(3,7$ and 28 days).

2- The decrease in both compressive and flexural strength was more obvious in specimens subjected to 
$700^{\circ} \mathrm{C}$ than that treated in water and for all references tested at $20^{\circ} \mathrm{C}$.

3- The minimum compressive strength loss was achieved when specimens $\left(\mathrm{B}_{3}\right)$ were exposed to $700^{\circ} \mathrm{C}$ and air treated then tested after 28 days, the decrease in strength was $(9.1 \%)$ compared to that of reference specimens tested at $20^{\circ} \mathrm{C}$ and the percentage loss in flexural strength was (9\%) for the same above case.

4- The minimum loss in compressive and flexural strength for specimens $\left(\mathrm{B}_{3}\right)$ was $(29.6 \%, 37.3 \%)$, respectively for the specimens at $700^{\circ} \mathrm{C}$ by water treated and tested after 28 days when comparing those results relative to the reference samples at $20^{\circ} \mathrm{C}$.

\section{References}

1- Aydin, S. (2008). Fire Safety Journal, Volume 43, Issue 8, November 2008, Pages 610 - 617

2- Aydin, S. Bardan, B. (2007). Cement and Concrete Research, Volume 37, Issue 6, 2007, Pages 988 995

3- Hossain, M.A., Islam, M.N., and Karim, M.R. (2006) $31^{\text {st }}$ conference on our world in concrete \& structures, 2006, Singapore

4- Iraqi standard Specification, ISQ No. 5:1984, Properties of Ordinary Portland Cement, 1984, Iraq

5- Iraqi standard Specification, ISQ No. 45:1984, Properties of Natural Aggregate Resources, 1984, Iraq

6- American Society for Testing and Materials, ASTM C494-99a, (2004), Standard Specification for Chemical Admixture for Concrete, Annual Book of ASTM Standards, Vol. 04-01, USA

7- American Society for Testing and Materials, ASTM C1437-, (2004), Standard Specification for Test Method for Flow of Hydraulic Cement Mortar, Annual Book of ASTM Standards, Vol. 04-02, USA
8- American Society for Testing and Materials, ASTM C305-99, (2004), Standard Practice for Mechanical Mixing of Hydraulic Cement Pastes and Mortars of Plastic Consistency, Annual Book of ASTM Standards, Vol. 04-01, USA

9- American Society for Testing and Materials, ASTM C0642-97, (2004), Standard Specification for Test Method for Density, Absorption, and Voids in Hardened Concrete, Annual Book of ASTM Standards, Vol. 04-02, USA

10-American Society for Testing and Materials, ASTM C0109-02, (2004), Standard Specification for Test Method for Compressive Strength of Hydraulic Cement Mortars, Annual Book of ASTM Standards, Vol. 04-01, USA

11-Shirkavand, M. and Baggott, R. (1995, Cement and Concrete Research, Volume 25, Issue 7, 1995, Pages $1512-1522$

12-Ahmed, A. H. and Abdul Kaream, O.M. (2010). Al Rafidain Engineering J., Vol. 18, No. 4, Pages 4354

13-American Society for Testing and Materials, ASTM C348-02, (2004), Standard Test Method for Flexural Strength of Hydraulic-Cement Mortars, Annual Book of ASTM Standards, Vol. 04-01, USA.

14-Georgali B.and Taskiridis P. E. (2005). Cement and Concrete Composites, Vol. 27, Pages 255 - 259

15- Fu, Y.F., Wong, Y.L. and Poon C.S,et al., (2004). Cement and Concrete Research, Volume 33, 2004, Pages 789 - 797

16- Serdar A, Halit Y. and Bulent B. (2008). Construction and Building Materials, Vol. 22, 2008. Pages 504- 512.

17- Fares H., Noumoure A., and Remond S. (2009). Cement and Concrete Research, Vol. 39, 2009. Pages $1230-1238$. 